\title{
PEMBERDAYAAN USAHA KECIL MENENGAH KULINER ROTI DI KABUPATEN SIMALUNGUN
}

\author{
Irfandi $^{*}$, Taufik Hidayat ${ }^{2}$, Rudi Salman ${ }^{3}$ \\ ${ }^{1}$ Jurusan Fisika, Fakultas Matematika dan Ilmu Pengetahuan Alam, UniversitasNegeri Medan, Medan, Indonesia \\ ${ }^{2} J u r u s a n$ Akuntansi, Fakultas Ekonomi, Universitas Negeri Medan, Medan, Indonesia \\ ${ }^{3} J u r u s a n$ Elektro, Fakultas Teknik, Universitas Negeri Medan, Medan, Indonesia \\ *Penulis Korespondensi: irfandi@unimed.ac.id
}

\begin{abstract}
Abstrak
Tujuan kegiatan untuk membantu mitra dalam menyelesaikan permasalahan yang dihadapinya, mulai dari aspek produksi maupun manajemen usaha sehingga diharapkan akan tercipta kemandirian secara ekonomi dan meningkatnya pendapatan usaha. Target khusus dalam kegiatan, dihasilkannya: 1) Alat pemanggang Roti 2) Blog sebagai pemasaran Daring; 3) Alat Kemasan; 4) Artikel ilmiah 5) Pelatihan Administrasi Keuangan. Metode yang digunakan untuk mencapai tujuan adalah metode pendidikan, penyuluhan, pelatihan produksi, pelatihan manajemen usaha, dan pendampingan. Hasil yang diperoleh adalah program berjalan sesuai dengan rencana Pelatihan IT ataupun pembuatan webblog yang memiliki kompetensi Sangat Baik (> 80) hanya 2 orang (5\%), pada pelatihan pembukuan keuangan Usaha terdapat 6 orang (16\%). Untuk kompetensi Baik (70-79) pada pelatihan IT sebanyak 8 Orang (21\%), pada pelatihan pembukuan yaitu 18 Orang (47\%). Untuk kompetensi Cukup (60-69) pada pelatihan IT sebanyak 19 Orang $(50 \%)$, pelatihan pembukuan terdapat 12 orang $(32 \%)$. Peserta dengan kriteria Kurang $(<60)$ pada pelatihan IT sebanyak 9 Orang $(24 \%)$, pelatihan Pembukuan sebanyak 2 Orang $(5 \%)$. Sedangkan pasca pemberian bantuan alat TTG yaitu Oven dan Sealer kepada kedua kelompok terdapat peninggkatan yang signifikan baik dari segi Produksi yang biasanya $10 \mathrm{~kg} / \mathrm{hari}$ meningkat rata-rata menjadi $20 \mathrm{~kg} / \mathrm{hari}$. Dan hal terbut juga berakibat pada peningkatan penjualan produk yang dipasarkan secara tradisional maupun dilakukan secara online
\end{abstract}

Kata kunci: Administrasi Keuangan, Teknologi Tepat Guna, Kemasan, Pemasaran Daring

\begin{abstract}
The purpose of activities to assist partners in solving problems faced, ranging from aspects of production and business management so that it is expected to create economic independence and increased operating revenues. Specific targets in activities, resulting: 1.) Baker toaster 2). Blog as an Online marketing; 3). Packaging Equipment; 4).The scientific article 5).The Financial Administration Training. The methods used to achieve the objectives are methods of education, counseling, production training, business management training, and mentoring. The results obtained are the program runs in accordance with the IT Training plan or the creation of a webblog that has very good competence (> 80) only 2 people (5\%), on the bookkeeping business financial training there are 6 people (16\%). For Good competence (70-79) on IT training as much as 8 People (21\%), on bookkeeping training that is 18 People (47\%). For the competence of Enough (60-69) on IT training as much as 19 People (50\%), bookkeeping training there are 12 people $(32 \%)$. Participants with Less criteria $(<60)$ on IT training as much as 9 People (24\%), Bookkeeping training as much as 2 People (5\%). While post-TTG tool assistance that is Oven and Sealer to both groups there is significant improvement in terms of Production which is usually $10 \mathrm{~kg} /$ day increased the average to $20 \mathrm{~kg} /$ day. And it also results in an increase in sales of products that are marketed traditionally or done online.
\end{abstract}

Keywords: Financial Administration, Appropriate Technology, Packaging, Online Marketing

\section{PENDAHULUAN}

Kemiskinan merupakan salah satu masalah yang memiliki beban cukup berat dalam pembangunan yang ditandai dengan kerentanan, ketidakberdayaan, keterisolasian, serta ketidakmampuan untuk menyampaikan aspirasi. Beberapa upaya dari pemerintah dalam mengentas kemiskinan telah dilakukan, tetapi hasilnya tidak begitu menunjukkan perubahan yang signifikan (Irfandi, 2015). Menurut hasil pendataan keluarga yang dilakukan oleh BKKBN, (BKKBN, 2015) diketahui bahwa $56 \%$ dari 39,4 juta keluarga Indonesia masih berada dalam tahap tertinggal yang termasuk dalam kategori keluarga Pra Sejahtera dan Keluarga Sejahtera I. Dari jumlah tersebut 11,5 juta 
keluarga tinggal di desa tidak tertinggal. Data ini menunjukkan bahwa sebahagian masyarakat kita masih hidup dalam kemiskinan dan belum dapat ikut serta dalam menikmati hasil-hasil pembangunan. Oleh karena itu sudah menjadi kesepakatan dan tekat bersama seluruh elemen bangsa dapat berperan dalam mengentaskan kemiskinan bagi masyarakat Indonesia. Upaya intensif penanggulangan kemiskinan adalah dengan ekonomi real kerakyatan yaitu dengan mendorong usaha kecil yang ada di masyarakat sebagai motor penggerak ekonomi kerakyatan (Kemenkeu, 2011). Home industri atau industri kecil menengah adalah salah satu penopang perekonomian negara, sekarang sudah banyak muncul berbagai home industri salah satunya adalah home industri makanan ringan seperti kelompok-kelompok usaha pembuat roti.

Berdasarkan hasil penelitian Simanungkalit tahun 2013 Faktor- faktor produksi home industri atau industri kecil makanan ringan yaitu, modal yang digunakan oleh para pengusaha home industri adalah modal sendiri yang digunakan secara berputar setiap harinya, bahan baku diperoleh dari pasar tradisional dan hasil perkebunan dengan cara sistem pesan, tenaga kerja home industri makanan ringan tersebut adalah keluarga dan tetangga disekitar (Simanungkalit, 2013). Peranan usaha kecil dalam perekonomian Indonesia dirasakan sangat penting, terutama dalam aspek-aspek seperti kesempatan kerja, pemerataan pendapatan, pembangunan ekonomi di pedesaan dan lain-lain (Santoso, 2009). Usaha untuk mengembangkan industri kecil di pedesaan merupakan langkah yang tepat sebagai salah satu instrumen kebijakan pemerintah untuk menanggulangi masalah-masalah ekonomi dan sosial yang dihadapi Indonesia pada saat ini. Di Nagori Dolok Maraja Kabupaten Simalungun bila kita tinjau dari aspek ekonomi masyarakat Nagori Dolok Maraja dapat digolongkan sebagai masyarakat produktif akan tetapi masih memiliki tingkat kesejahteraan yang masih jauh dari sejahtera. Hal ini terungkap bila kita lihat dari data tentang ragam profesi dan kondisi ekonomi warga nagori, karena profesi penduduk masih didominasi oleh karyawan perkebunan karet swasta, dan sebagian besar warga yang bekerja sebagai karyawan perkebunan didominasi oleh buruh penyadap karet atau lebih dikenal sebagai "penderes" getah. Jumlah warga desa yang bekerja sebagai karyawan perusahan karet yaitu sebanyak 730 jiwa. Lalu disusul profesi sebagai petani 451 jiwa, pertanian yang digeluti antara lain adalah petani karet, ubi, pisang, jagung dan sawit. Pada posisi ketiga profesi yang banyak digeluti oleh warga nagori dolok maraja adalah Buruh 320 jiwa. Buruh disini adalah buruh harian lepas yaitu buruh yang bekerja harian tanpa ada penghasilan tetap, seperti buruh pabrik, buruh tani dan buruh bangunan. (Monografi Dolok Maraja, 2013)
Tabel .1 Keadaan Penduduk menurut Pekerjaan Per Jiwa

\begin{tabular}{lll}
\hline NO & JENIS PEKERJAAN & JUMLAH \\
\hline 1. & Home Industri & 37 \\
2. & Petani & 451 \\
3. & Pedagang & 161 \\
4. & PNS & 75 \\
5. & Karyawan & 730 \\
6. & Supir & 120 \\
7. & Buruh & 320 \\
8. & Tukang Bangunan & 95 \\
\hline Jumlah & $\mathbf{2 6 8 6}$ \\
\hline
\end{tabular}

Dari data pada tabel Monografi Nagori Dolok Maraja tahun 2013 dapat kita lihat bahwa pemberdayaan home industri atau usaha rumahan menduduki posisi terakhir atau ke 8 dengan jumlah 37 jiwa yang menekuni profesi sebagai pengelola home industri. selain itu juga Home Industri yang dikelolah oleh masyarakat Nagori Dolok Maraja mayoritas berupa makanan ringan, baik itu dalam bentuk roti kering, roti basah, Keripik ubi, keripik pisang ataupun kue-kue tradisional yang belum menyentuh pada segmen bidang ekonomis atau membawa kesejahteraan secara umum di Nagori Dolok Maraja. Karena selama ini kegiatan home industry yang dilakukan masyarakat Nagori Dolok Maraja tidak banyak yang bertahan lama dan hanya bersifat sampingan, jadi bila terkendala dengan sedikit masalah baik masalah keuangan atau masalah pemasaran banyak industri rumah tangga ini berhenti, dan banyak para pelaku home industry ini beralih profesi sebagai buruh maupun sebagai karyawan di pabrik sekitar kecamatan Tapian Dolok. (sumber: hasil wawancara dengan kepala Nagori, Januari 2015).

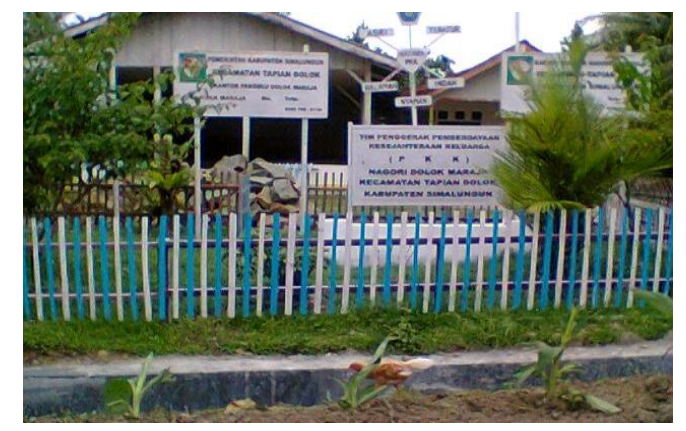

Gambar 1. Kantor Pangulu Nagori Dolok Maraja

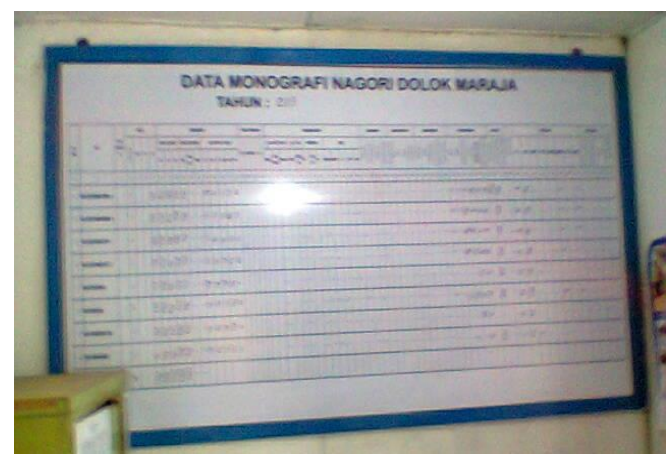

Gambar 2. Data Monografi Nagori 
Selain masalah pemasaran ada beberapa hal kendala yang mendasar yang dialami oleh industri rumah tangga dinagori Dolok Maraja antara lain yaitu masalah teknologi tepat guna yaitu penggunaan oven yang masih manual sehingga proses pemanggangan tidak merata dan teksturnya kurang menarik, dan dalam hal pengemasan produk hanya menggunakan plastik biasa (Plastik asoy) sehingga membuat produk tidak terlihat higienis dan mempengaruhi daya beli konsumen secara langsung. Akan tetapi usaha home industry ini memiliki potensi untuk dapat berkembang karena bila dilihat usaha roti ini cukup diminati oleh masyarakat Simalungun dan Sumatera Utara pada umumnya. Bahkan panganan roti ini menjadi comodity yang cukup diandalkan sebagai oleh-oleh, seperti roti ganda, bolu gulung meranti dan roti“ketawa”, yang cukup dikenal luas dan diminati masyarakat, hal ini terbukti dengan beberapa kali produk roti industri rumah tangga dari Nagori Dolok maraja mengikuti Pameran baik tinggkat kecamatan Tapian Dolok hingga tingkat Propinsi Sumatera Utara. Hal yang menjadi peluang terbesar saat ini dalam hal pemasaran produk adalah Nagori Dolok Maraja merupakan daerah penyangga 2 lokasi strategis di Kabupaten Simalungun yaitu Danau Toba merupakan ikon pariwisata Sumatera Utara. Di tengah Danau Toba ada Pulau Samosir. Geoparkkalendra toba daerah wisata Danau Toba yangdiakui oleh United Nations Educational, Scientific and Cultural Organisation (UNESCO) atau Organisasi PBB untuk Pendidikan, Ilmu Pengetahuan, dan Kebudayaan. Dan selain itu juga, daerah yang menjadi pusat pengembangan kawasan industri Sei Mangkei, Kabupaten Simalungun, Sumatera Utara, menjadi kawasan ekonomi khusus pertama di Indonesia. Yang kedua lokasi tersebut merupakan tempat pemasaran yang strategis dan juga memperkenalkan produk Home industry,yang membawa implikasi terhadap kesejahteraaan masyarakat di Nagori Dolok Maraja.

\subsection{Aspek Produksi dan Manajemen Usaha Mitra} Industri rumah tangga yang menjadi mitra 1 adalah Anugrah dan mitra 2 Industri rumah tangga Bahapal Jaya yang berada di Nagori Dolok Maraja Kecamatan Tapian Dolok Kabupaten Simalungun. Usaha-usaha rumahan tersebut berjarak $\pm 100 \mathrm{~km}$ dari Universitas Negeri Medan dan dapat ditempuh dengan anggkutan umum selama 2 jam 22 menit sampai kelokasi, industri rumahtangga Anugrah dan Bahapal Jaya merupakan usaha kecil dibawah binaan PKK Nagori Dolok Maraja yang memproduksi berbagai jenis rotikering dan basah. Berdasarkan hasil survey penulis (15 Februari 2015) adalah sebagai berikut:

1. Usaha industri rumah tangga ini memproduksi aneka roti sesuai dengan pesanan ataupun yang biasa setiap hari di beli oleh konsumen.

2. Usaha industri rumah tangga ini, setiap harinya memproduksi roti dengan bermacam variasi sebanyak $10-20 \mathrm{~kg}$ per hari.

3. Untuk memanggang roti, industri rumah tangga ini masih menggunakan konvensional atau menggunakan oven arang biasa yang tidak dapat diatur berapa suhu serta waktunya.

4. Pengemasan roti produksi industri rumah tangga Belum memenuhi standart karna hanya menggunakan Plastik biasa (Plastik Asoy) sehingga higienitas serta tampilannya kurang menarik

5. Pemasaran yang dilakukan oleh mitra hanya kesekolah-sekolah, warga sekitar kecamatan Tapian Dolok, dan belum dikenal luas

Bila dilihat kondisi manajemen yang diterapkan oleh mitra usaha industri rumah tangga ini masih menggunakan manajemen sederhana secara kekeluargaan, dimana pengelolaan administrasi yang meliputi pengaturan kerja, pembiayaan, produksi dan SDM masih dilakukan secara sederhana. Untuk pengelolaan industri rumah tangga, semuanya masih di pegang oleh pemilik usaha, baik pengadaan bahan baku, pengelolaan produksi, tenaga kerja, dan penjualan. Meskipun menganut manajemen kekeluargaan, sistem pembagian kerja sudah teroganisir dengan baik, artinya masing-masing pekerja sudah mempunyai tugas dan tanggungjawab untuk masing-masing bidang yang menjadi tugasnya.

Melihat potensi usaha industri rumah tangga ini cukup besar dan didukung dengan potensi sumberdaya manusia kiranya diperlukan suatu upaya untuk mengembangkannya. Salah satunya yaitu memberikan pengetahuan dan teknologi tepat guna. Mengingat cukup besarnya potensi usaha dan didukung dengan potensi sumberdaya manusia dan secara intens didampingi oleh PKK Nagori Dolok Maraja. Oleh karena itu diperlukan suatu upaya untuk memberdayakan pengusaha industri rumah tangga, salah satunya yaitu dengan memberikan teknologi tepat guna yaitu oven serba guna dan alat untuk memperbaiki packing kemasan serta desain kemasannya. sehingga produk usaha industri rumah tangga ini akan menghasilkan rotiyang berkualitas baik serta mampu mengurangi biaya produksi dalam hal pemanggangan bahan, sehingga dapat meningkatkan pendapatan pengusaha industri rumah tangga.

\subsection{Permasalahan Mitra}

Industri rumah tangga yang menjadi mitra 1 adalah Anugrah dan mitra 2 Industri rumah tangga Bahapal Jaya yang berada di Nagori Dolok Maraja Kecamatan Tapian Dolok Kabupaten Simalungun. Permasalahan yang dihadapi ke dua Mitra adalah : (1) Harga jual roti produksi industri Rumah Tangga sangat murah, karena desain dan tampilan yang kurang menarik serta kurang higienis karena memakai plastik asoy (2) mitra dan masyarakat yang memproduksi roti, memiliki pengetahuan yang masih sangat terbatas khususnya tentang kandungan gizi roti dan teknik variasi maupun ragam bentuk dan rasa roti, (3) dan belum dapat memanfaatkan (teknologi tepat guna), oven serbaguna, mesin packing (siller), dan dalam hal mendesain kemasan. 


\section{METODE PELAKSANAAN \\ 2.1 Penentuan Permasalahan Prioritas Mitra Baik Produksi}

Mitra 1 yaitu usaha rumah tangga atau Home industri Anugrah, ini terdiri dari 5 orang anggota, usaha ini bergerak di bidang usaha pembuatan Roti kering dan Bolu gulung untuk meningkatkan pendapatan keluarga. Usaha rumahan ini didirikan pada tahun 2008 oleh Ibu Riswati, industri rumah tangga ini merupakan binaan dari PKK Nagori Dolok maraja kecamatan Tapian Dolok Kabupaten Simalungun. Dalam kelompok ini tidak hanya bergerak diusaha RotiKering saja, akan tetapi ada juga yang usaha roti kelapa, roti cokelat, roti paha ayam dan lainya. Lokasi usaha ini terletak di Dusun I Nagori Dolok Maraja Desa Kecamatan Tapian Dolok. Tempat Usaha Rumah tangga atau home industri ini terletak di dusun I di. Home industry ini masih menggunakan peralatan sederhana dalam melakukan proses produksi. Dalam setiap harinya home industry ini memproduksi roti kurang lebih sekitar 10-20 kg/hari. Harga jual rotiyang diproduksi oleh usaha rumahan anugrah dipasarkan dengan harga berkisar Rp. 1000,-/buah. Untuk pemasaran Roti biasanya menunggu pesanan atau, dijual keliling kewarung-warung atau sekolah-sekolah disekitar kecamatan Tapian Dolok. Yang menjadi permasalahan pada mitra yaitu diperlukannya pengetahuan tentang desain kemasan, karena roti dijual perbuah dan menggunakan plastik biasa (plastik asoy) dan teknologi tepat guna yaitu oven serbaguna yang menggunakan gas dan listrik karena terkadang gas sangat sulit didapat dan terbatas sedangkan listrik sering terjadi pemadaman bergilir jadi mitra membutuhkan alat oven serbaguna yang dapat menggunakan listrik dan gas. Alat packaging serta teknologi pengolahan roti, agar dihasilkannya produknya lebih menarik. Kondisi manajemen yang diterapkan dalam usaha rumah tangga yang dikelola oleh mitra 1 masih menggunakan manajemen sederhana secara kekeluargaan dan belum dikelola sebagaimana mestinya. Meskipun menganut manajemen sederhana, sistem pembagian kerja sudah terorganisir dengan baik, artinya masing-masing karyawan sudah punya tugas/pekerjaan masing-masing sehingga tidak terjadi kerja yang tumpang tindih.

Mitra 2 yaitu industri rumah tangga Bahapal Jaya, industri kecil ini terdiri dari 5 orang yang bekerja memproses dari awal bahan hingga produksi akhir, usaha ini bergerak di bidang usaha pembuatan roti, untuk meningkatkan pendapatan keluarga. Usahanya ini dijalankan masih sangat sederhana, usaha ini dibuat dirumah Pak Sairikdengan menggunakan alat yang masih sangat sederhana. Pemasaran usaha ini masih dipasarkan diwarung-warung sekitar desa dan dijualkan dengan cara berkeliling kekantor-kantor dan sekolah-sekolah disekitar kecamatan Tapian Dolok. Usaha ini didirikan tahun 2010 oleh Bapak Sairik. Industri rumah tangga ini beralamat di Nagori dolok maraja Dusun II atas kecamatan tapian dolok, Produksi dari usaha Rumah Tangga ini hanya sekitar 5-10 $\mathrm{Kg} / \mathrm{hari}$. Kemasan yang digunakan juga sangat sederhana, harga jualnya Rotiyang diproduksi oleh usaha kecil Bahapal jaya dipasarkan dengan harga berkisar Rp. 1000,-/bungkus. Untuk pemasaran masih dipasarkan oleh anggota kelompok saja. Yang menjadi permasalahan pada Mitra 2, yaitu diperlukannya pengetahuan tentang desain kemasan dan teknologi tepat guna yaitu alat untuk memanggang roti (oven serbaguna) dan alat packaging serta teknologi pengolahan roti dengan citarasa yang bervariasi, agar dihasilkannya produk roti yang lebih menarik.Pada mitra 2 juga sangat diperlukan metode pemasaran yang efektif dan pembukuan keuangan yang lebih baik.

\subsection{Penentuan Permasalahan Prioritas Mitra Baik Produksi Manajemen}

Kondisi manajemen yang diterapkan dalam usaha Rumah Tangga yang dikelola oleh mitra 1 Anugrah dan mitra 2Bahapal Jaya masih menggunakan manajemen sederhana secara kekeluargaan dan belum dikelola sebagaimana mestinya. Meskipun menganut manajemen sederhana, sistem pembagian kerja sudah terorganisir dengan baik, artinya masing-masing karyawan sudah punya tugas/pekerjaan masing-masing sehingga tidak terjadi kerja yang tumpang tindih. Bila dilihat dari kemampuan produksi dapat disimpulkan bahwa usaha pembuatan roti yang dilakukan oleh mitra sudah cukup pontensial untuk dikembangkan.

Meskipun menganut manajemen kekeluargaan, sistem pembagian kerja sudah terorganisir dengan baik. Dan bila dilihat dari kemampuan menjual hasil rumah tangga cukup potensial untuk dikembangkan karena potensi sumberdaya manusia dan dukungan pemerintahan nagori setempat yang begitu besar.maka diperlukan suatu upaya untuk memberdayakan mitra, salah satunya yaitu melalui teknologi tepat guna dan memberikan pendidikan, pelatihan produksi, manajemen usaha dan pemasaran. Diharapkan mitra nantinya memiliki kuantitas dan kualitas, sehingga output yang dihasilkan dapat berkembang menjadi wirausaha baru bagi masyarakat untuk meningkatkan pendapatan dengan skema pendampingan sebagai berikut : 
PERMASALAHAN

1. Lemahnya memanfaatkan teknologi tepat guna
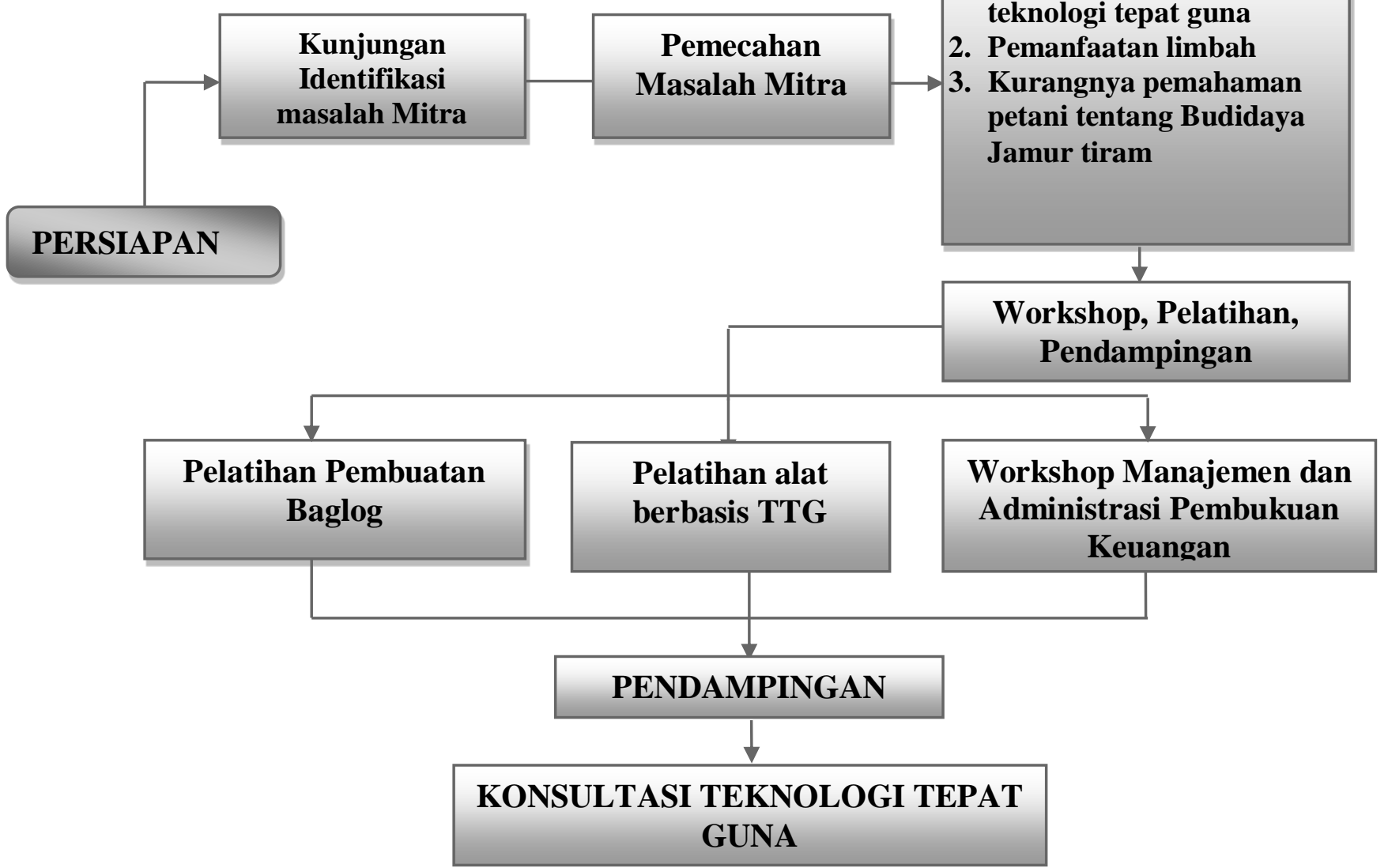

Gambar 3. Skema Program dalam Menyelesaikan Masalah Mitra (Irfandi, 2017)

\subsection{Metode Pendekatan Untuk Menyelesaikan Persoalan Mitra}

Berdasarkan permasalahan yang telah di kemukakan, maka dalam kegiatan $\mathrm{I}_{\mathrm{b}} \mathrm{M}$ ini metode pendekatan yang digunakan adalah metode pendidikan, penyuluhan, pelatihan produksi, pelatihan manajemen usaha, dan pendampingan. Metode pendekatan yang ditawarkan untuk memecahkan masalah tersebut secara operasional adalah sebagai berikut:

- Memberikan oven a untuk mendapatkan keseragaman dan tekstur roti yang baik

- Memberikan mesin kemasan agar kemasan produk tidak bocor.

- Memberikan pelatihan pembuatan blog untuk memasarkan produk secara daring

- Memberikan pendidikan dan pelatihan penyusunana laporan keuangan

\subsection{Prosedur Kerja Untuk Mendukung Realisasi} Metode Yang Ditawarkan

Prosedur kerja yang akan dilakukan untuk mendukung realisasi metode yang di tawarkan sebagai berikut:

1) Memberikan pelatihan produksi roti ditinjau dari segi kesehatan
2) Memberikan pelatihan manajemen usaha, dengan tujuan untuk meningkatkan keterampilan pemilik usaha (Mitra) dalam menerapkan manajemen di bidang organisasi, produksi, keuangan, administrasi, harga jual produk, konsumen, dan teknik pemasaran

3) Memberikan pelatihan desain

4) Memberikan pelatihan pengelolaan blog untuk pemasaran daring

5) Memberikan pelatihan pembukuan keuangan

6) Pendampingan kegiatan

\subsection{Rencana Kegiatan dan Partisipasi Mitra}

Kegiatan ini direncanakan dilakukan dengan pendekatan metode pendidikan, penyuluhan, pelatihan produksi, pelatihan manajemen usaha, rancang bangun, dan pendampingan. Rencana kegiatan ini meliputi langkah-langkah sebagai berikut: 
Tabel 2. Rencana kegiatan

\begin{tabular}{|c|c|c|c|c|}
\hline No & Aplikasi Kegiatan & Metode Pendekatan & Target & Partisipasi Mitra \\
\hline 1. & $\begin{array}{l}\text { Memberikan } \\
\text { Mesin pemanggang } \\
\text { Roti }\end{array}$ & $\begin{array}{l}\text { Praktik } \\
\text { menggunakanmesin } \\
\text { Pemanggang rotidan } \\
\text { pelatihan produksi }\end{array}$ & $\begin{array}{lr}\text { Rumah } & \text { Tangga } \\
\text { berkualitas } & \text { dengan } \\
\text { potongan yang rata }\end{array}$ & $\begin{array}{l}\text { Menyediakan bahan baku, } \\
\text { tempat, Ikut praktik } \\
\text { menggunakan } \\
\text { mesin pemanggang roti }\end{array}$ \\
\hline 2. & $\begin{array}{l}\text { Memberikan mesin } \\
\text { packaging }\end{array}$ & $\begin{array}{l}\text { Praktik menggunakan } \\
\text { mesin packaging }\end{array}$ & $\begin{array}{l}\text { Rumah Tangga dalam } \\
\text { kemasan yang layak } \\
\text { untuk di pasarkan di } \\
\text { supermarket }\end{array}$ & $\begin{array}{l}\text { Ikut pelatihan menggunakan } \\
\text { mesin packaging dan aktif } \\
\text { bertanya untuk hal yang } \\
\text { belum dimengerti }\end{array}$ \\
\hline 3. & $\begin{array}{l}\text { Memberikan } \\
\text { pendidikan dan } \\
\text { pelatihan produksi }\end{array}$ & $\begin{array}{ll}\text { Pendidikan } & \text { dan } \\
\text { pelatihan produksi } & \end{array}$ & Inovasi produk & $\begin{array}{l}\text { Ikut pendidikan } \\
\text { pelatihan produksi }\end{array}$ \\
\hline 4 & $\begin{array}{l}\text { Memberikan } \\
\text { Pendidikan dan } \\
\text { pelatihan pembuatan } \\
\text { web blog pemasaran } \\
\text { online }\end{array}$ & $\begin{array}{lr}\text { Pendidikan } & \text { dan } \\
\text { pelatihan } & \text { pembuatan } \\
\text { blog untuk } & \text { pemasaran } \\
\text { online } & \end{array}$ & $\begin{array}{l}\text { Pemasaran dan } \\
\text { mempromosika } \\
\text { produk } \\
\text { Kepada konsumen } \\
\text { yang lebih luas }\end{array}$ & $\begin{array}{l}\text { Ikut pendidikan dan } \\
\text { pelatihan pemasaran } \text { Online }\end{array}$ \\
\hline 5 & $\begin{array}{l}\text { Pendidikan dan } \\
\text { pelatihan penyusunan } \\
\text { laporan keuangan }\end{array}$ & $\begin{array}{l}\text { Pendidikan dan } \\
\text { pelatihan penyusunan } \\
\text { laporan keuangan }\end{array}$ & $\begin{array}{l}\text { Mampu menyusun } \\
\text { laporan keuangan }\end{array}$ & $\begin{array}{lr}\text { Aktif mengikuti } & \text { pelatihan } \\
\text { penyusunan } & \text { laporan } \\
\text { keuangan serta bertanya } \\
\text { untuk hal yang belum } \\
\text { dimengerti }\end{array}$ \\
\hline
\end{tabular}

\subsection{Luaran dan Prosedur}

Luran yang akan dihasilkan adalah sebagai berikut:

1. Alat Pemanggang Roti

2. Sealer

3. Laporan keuangan

4. Web blog sebagai media promosi dan pemasaran online

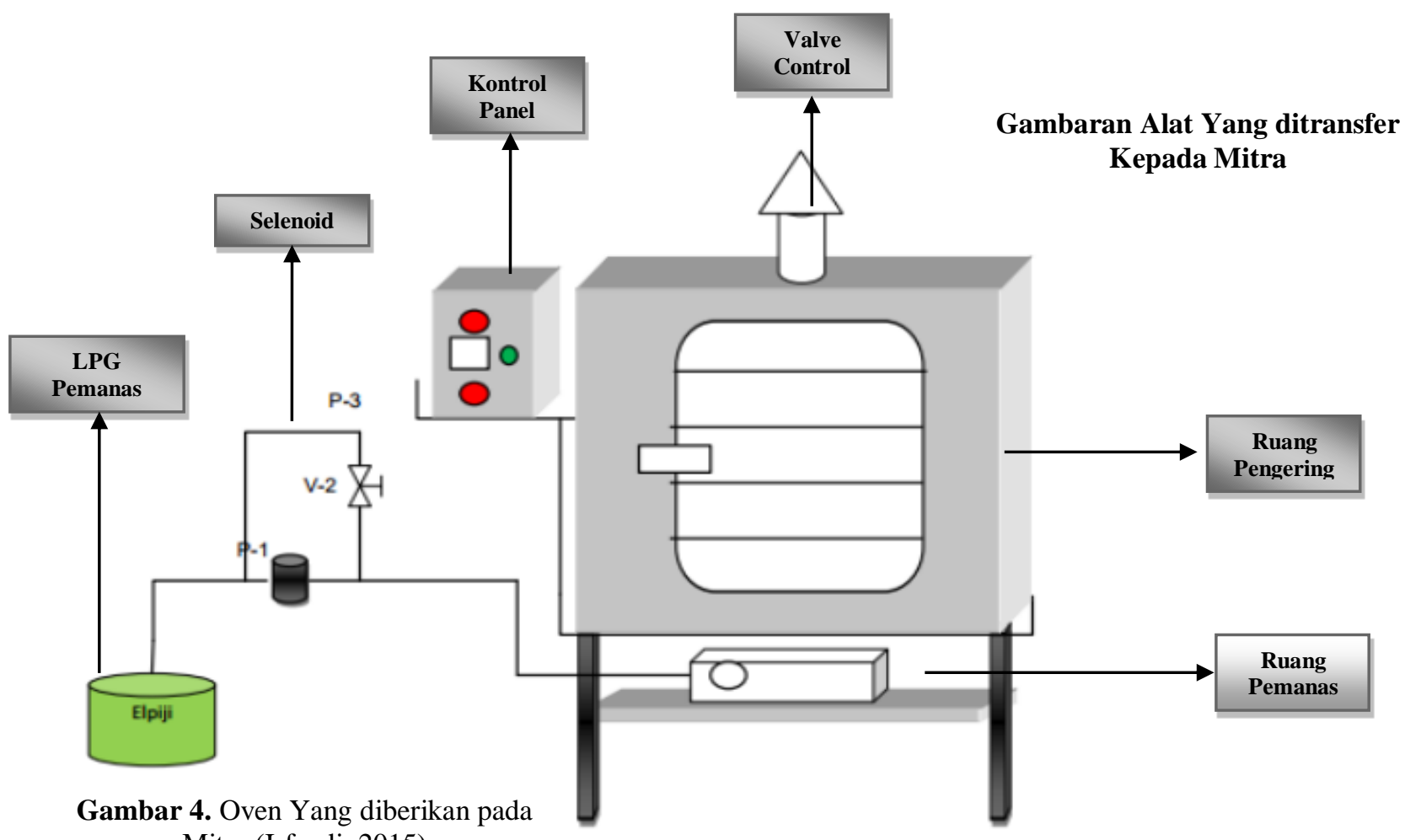




\section{HASIL DAN PEMBAHASAN}

\subsection{Lokasi}

Kegiatan pengabdian kepada masyarakat ini dilaksanakan di rumah warga kelompok UMKM Kuliner Roti Anugrah dan Bahapal Jaya serta di Balai Pertemuan Warga Nagori Dolok Maraja Kecamatan Tapian Dolok Kabupaten Simalungun.

\subsection{Hasil Pelaksanaan Kegiatan}

Pelaksanaan Kegiatan Kelompok Usaha Rumah Tangga Kuliner Roti dilakukan secara bertahap dan sistematis. Adapun kegiatan-kegiatan yang telah dilakukan meliputi tahapan sebagai berikut:

\section{1) Persiapan}

a. Persiapan pelaksanaan kegiatan (koordinator tim pelaksana dengan LPM dan Usaha mitra)

b. Tim pengabdi melakukan Pengurusan perijinan kepada aparatur Nagori Dolok Maraja yang dijadikan lokasi pengabdian

c. Ketua tim bersama anggota pengabdi melakukan Penyusunan jadwal kegiatan dan melakukan pembagian kerja

\section{2) Operasional Kegiatan}

a. Tim pengabdi melakukan Temu wicara dengan kelompok mitra untuk pemantapan kegiatan

b. Pengumpulan bahan dan peralatan yang dibutuhkan dalam kegiatan Kelompok Usaha Rumah Tangga Kuliner Roti

c. Pemberian bahan dan alat sealer kemasan agar produk dapat dipasarkan dengan kemasan yang higienis dan terjamin mutu serta tahan lama

d. Memberikan pendampingan dan penyuluhan tentang Komposisi Roti, zat gizi, Kebersihan serta keamanan penggunaan pewarna makanan yang terkandung didalam roti tersebut dengan pemateri dari Dinas Kesehatan Kota Medan dan mahasiswa tata boga

e. Pelatihan desain kemasan dan Pelatihan pembukuan dan administrasi Usaha yang dilakukan Oleh Taufik Hidayat, SE., M.Si

f. Pelatihan Pemasaran secara Online dengan membuat e-mail, media sosial Blog untuk memasarkan produk Oleh Irfandi, M.Si dan Salman, ST., MT

g. Penyerahan oven pemasak roti yang diserahkan kepada, yang diserahkan kepada kelompok serta disaksikan oleh pangulu Nagori Dolok Maraja beserta perangkat Nagori yang ada di Simalungun.

\subsection{Pembahasan}

Kegiatan pemantauan dan evaluasi dilakukan untuk mengetahui sejauh mana keberhasilan kegiatan dapat tercapai. Evaluasi dilakukan pada saat pelaksanaan kegiatan baik diawal, proses kegiatan berlangsung dan setelah kegiatan selesai dilakukan.kegiatan pemantauaan dilakukan dengan menggunakan pengamatan langsung terhadap pola, model, proses dan hasil kegiatan yang dilaksanakan dengan data yang diperoleh secara deskriftif dengan persentase, skor penilaian:

$$
\begin{array}{lll}
- & >80 & =\text { Sangat Baik } \\
- & 70-79 & =\text { Baik } \\
- & 60-69 & =\text { Cukup } \\
- & <60 & =
\end{array}
$$

\section{1) Pembahasan awal kegiatan}

Tempat kegiatan dilaksanakan di rumah seorang Ketua kelompok Usaha Kuliner Roti Anugrah, rumah tersebut sangat sesuai sebagai tempat pelatihan hal disebabkan luasnya ruangan untuk melakukan Pendampingan dan Penyuluhan tentang Komposisi, Higienitas, Kerapihan dan Kebersihan produk dapat berjalan secara efektif dan efisien. Sebelum kegiatan IbM dilaksanakan tim terlebih dahulu mempersiapkan alat dan bahan yang akan dipergunakan untuk pembuatan produk-produk kuliner Roti. Evaluasi dilakukan untuk mengetahui hasil yang dicapai oleh seluruh peserta kegiatan dari 2 kelompok UMKM kuliner Roti yaitu bahapal Jaya dan Anugrah. Evaluasi dilakukan pasca dilakukan pendampingan dan penyuluhan tentang kuliner roti ditinjau dari sisi kesehatannya, kebersihan lat, kebersihan Produk serta kandungan nutrisi roti dan kerapian roti pada saat pembuatan . Dalam evaluasi digunakan instrumen pengamatan langsung dengan kriteria penilaian yaitu mengambil ukuran yaitu: Pemilihan Kandungan komposisi Bahan, Pengolahan Produk Sisa, kebersihan produk, kebersihan alat.

Tabel .3 Nilai Rata-Rata Hasil pendampingan dan penyuluhan tentang kuliner roti ditinjau dari sisi kesehatannya

\begin{tabular}{|l|c|c|}
\hline \multicolumn{1}{|c|}{$\begin{array}{c}\text { Aspek } \\
\text { penilaian }\end{array}$} & $\begin{array}{c}\text { Rata-rata } \\
\text { Skor }\end{array}$ & Kategori \\
\hline $\begin{array}{l}\text { Pemilihan } \\
\text { Kandungan Gizi } \\
\text { Bahan }\end{array}$ & 78,92 & Baik \\
\hline $\begin{array}{l}\text { Pengolahan } \\
\text { Produk sisa }\end{array}$ & 75 & Baik \\
\hline $\begin{array}{l}\text { Kebersihan } \\
\text { Produk }\end{array}$ & 76,5 & Baik \\
\hline Kebersihan alat & 78 & Baik \\
\hline $\begin{array}{l}\text { Kerapian } \\
\text { Produk }\end{array}$ & 81 & Sangat Baik \\
\hline
\end{tabular}

Berdasarkan hasil rata-rata skor nilai dari pendampingan dan penyuluhan yang dilakukan oleh tim LPM Unimed untuk rata-rata pemilihan bahan pembuatan roti dipilih secara baik walaupun belum mampu terukur secara akurat kandungan gizi dan komposisi dari tiap produk yang dihasilkan, namun secara umum bahan pada proses pemilihan bahan mendapatkan skor rata-rata 78,92 dengan Kategori Baik. Kelompok telah mampu membuat olahan roti sisa (return) kalau biasanya dibuang begitu saja yang membuat hama lalat dan tikus semangkin banyak, saat ini roti sisa penjualan dimanfaatkan sebagai pakan 
ternak baik sapi, kambing dan bebek sehingga manfaatnya dapat lebih dirasakan dari produksi telur dan daging dengan nilai rata-rata $75 \%$ dengan Kategori Baik. Untuk kebersihan produk olahan kuliner roti masing-masing kelompok mendapatkan nilai 76,5\% dengan Kategori Baik. Sedangkan untuk kebersihan alat yang dipergunakan dalam melakukan produksi secara umum rata-rata kelompok mendapatkan nilai $78 \%$ dengan Kategori baik, karena para pelaku usaha telah dapat membedakan mana barang-barang yang dijadikan sebagai alat produksi dengan barang-barang yang digunakan dalam kehidupan sehari-hari atau untuk kegiatan memasak untuk keluarga. Sedangkan kerapian Produk pada kedua kelompok sudah masuk kategori sangat baik dengan nilai 81, karena bentuk dari produk yang dikeluarkan dengan aneka bentuk yang cukup menarik baik roti pisang coklat, roti paha ayam dan bolu gulung. Untuk lebih jelasnya dapat terlihat pada grafik di bawah ini:

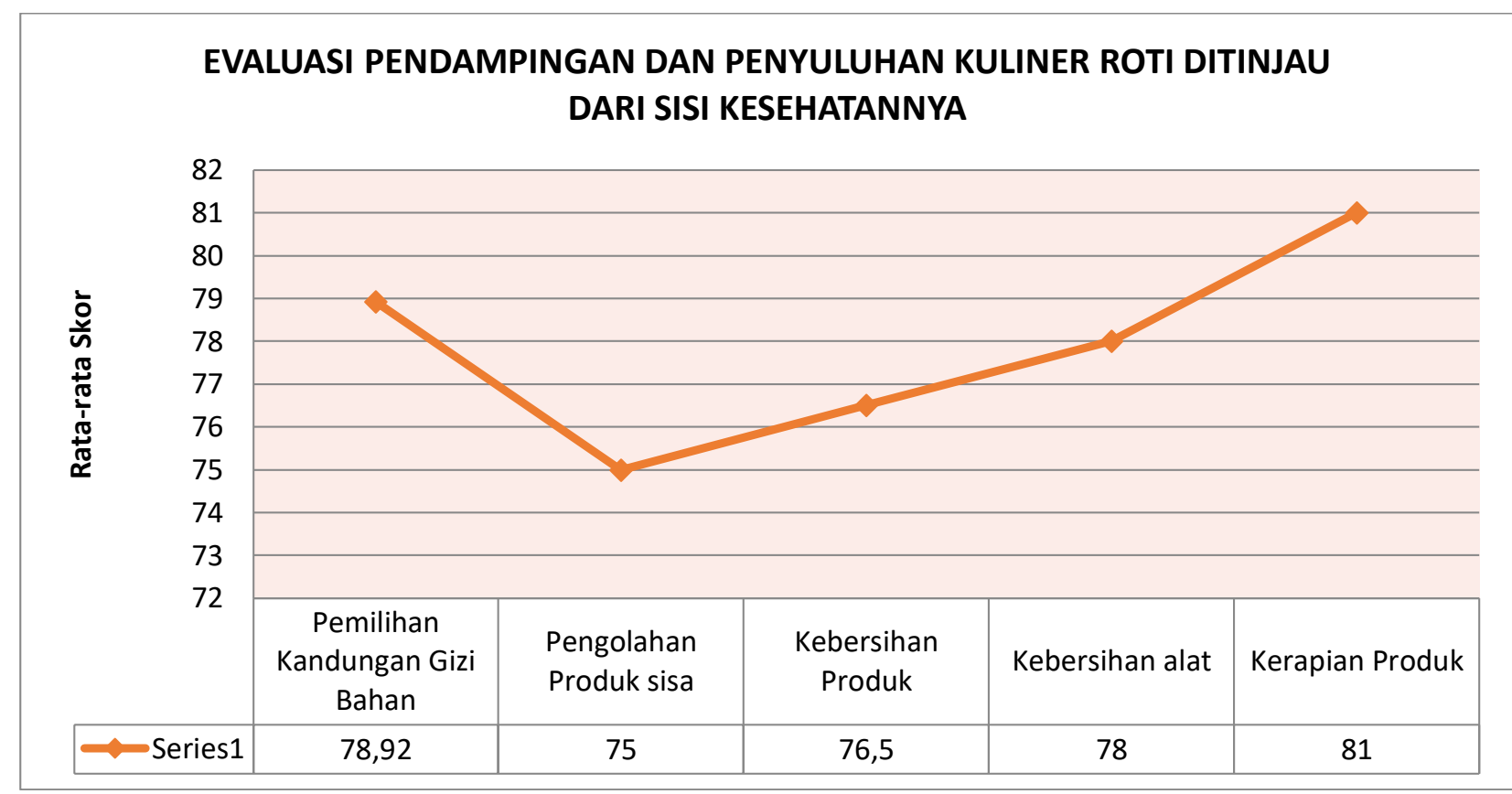

Gambar 5. Grafik Evaluasi Pendampingan dan Penyuluhan Kuliner Roti ditinjau dari sisi Kesehatannya

\section{2) Pembahasan Proses Kegiatan}

Penilaian dilaksanakan pada saat pelatihan berlangsung dengan mengamati cara kerja anggota kelompok dengan indikator rencana kerja, pelaksanaan proses kerja dan penggunaan waktu. Pada saat proses kerja peserta dalam pembuatan Manajemen Pemasaran dengan IT ataupun pembuatan webblog dan Pembukuan administrasi keuangan tim pelaksana memantau/ mengawasi kinerja peserta. Hampir keseluruhan peserta dapat melaksanan kegiatan ini hal ini dapat terlihat dari daftar hadir peserta sebanyak $95 \%$ dari 38 dari 40 peserta hadir pada saat pelaksanaan kegiatan. Proses tanya jawab peserta dan pelaksana kegiatan terjadi sangat terbuka sehingga suasana pelatihan menjadi hangat dan dapat benar-benar memahami materi yang diberikan. Untuk kedua UMKM kuliner Roti yaitu Anugrah dan bahapal Jaya telah Memiliki webblog penjualan di dunia maya yaitu: http://umkmanugrah.blogspot.co.id dan http://bahapaljaya.blogspot.co.id/ yang telah melakukan penjualan secara Online. Banyaknya peserta antusias hadir dikarenakan lokasi pelatihan dilaksankan di balai Nagori Desa dolok maraja ataupun di Pusat Pemerintahan Nagori sehingga peserta begitu antusias untuk mengikuti kegiatan pelatihan Pembukuan dan Pelatihan IT pembuat strategi pemasaran secara on-line dengan membuat webblog dapat dilihat dari data tabel 4.2 dibawah ini:

Tabel 4. Hasil Kemampuan Peserta Pada Pelatihan IT dan Pembukuan usaha

\begin{tabular}{|l|c|c|}
\hline Kriteria Kemampuan & $\begin{array}{c}\text { Pelatihan } \\
\text { IT (Orang) }\end{array}$ & $\begin{array}{c}\text { Pelatihan } \\
\text { Pembukuan } \\
\text { (Orang) }\end{array}$ \\
\hline Sangat Baik $(>80)$ & 2 & 6 \\
\hline Baik $\quad(70-79)$ & 8 & 18 \\
\hline Cukup $\quad(60-69)$ & 19 & 12 \\
\hline Kurang $(<60)$ & 9 & 2 \\
\hline Jumlah & $\mathbf{3 8}$ & $\mathbf{3 8}$ \\
\hline
\end{tabular}

Dari data pada Tabel 3.2 dapat dilihat untuk Pelatihan IT ataupun Pembuatan webblog yang memiliki kompetensi Sangat Baik (> 80) hanya 2 orang ataupun $5 \%$ dari jumlah seluruh peserta dan pada pelatihan pembukuan keuangan Usaha terdapat 6 orang atau $16 \%$ yang memiliki kopetensi sangat baik. Untuk kompetensi Baik (70-79) pada 
pelatihan Pemasaran secara IT sebanyak 8 Orang atau $21 \%$ dan pada pelatihan pembukuan cukup signifikan yaitu 18 Orang atau sebesar $47 \%$ memiliki kompetensi baik. Untuk kompetensi Cukup (60-69) dari tabel dapat kita lihat pada pelatihan IT sebanyak 19 Orang ataupun 50\% dari jumlah peserta dan ini angka tertinggi pada pelatihan ini, sedangkan pada pelatihan pembukuan keuangan Usaha terdapat 12 orang dengan kompetensi cukup. Dan terakhir peserta dengan kriteria Kurang $(<\mathbf{6 0})$ pada pelatihan IT sebanyak 9 Orang atau $24 \%$ dan untuk pelatihan Pembukuan Keuangan Usaha sebanyak 2 Orang atau $5 \%$. Banyaknya peserta dengan kompetensi cukup pada pelatihan IT karena banyak Peserta yang tidak membawa Laptop serta jaringan yang cukup lambat sehingga banyak peserta yang tidak dapat mengulang materi yang telah diberikan. Untuk lebih jelasnya dapat dilihat pada grafik dibawah ini:

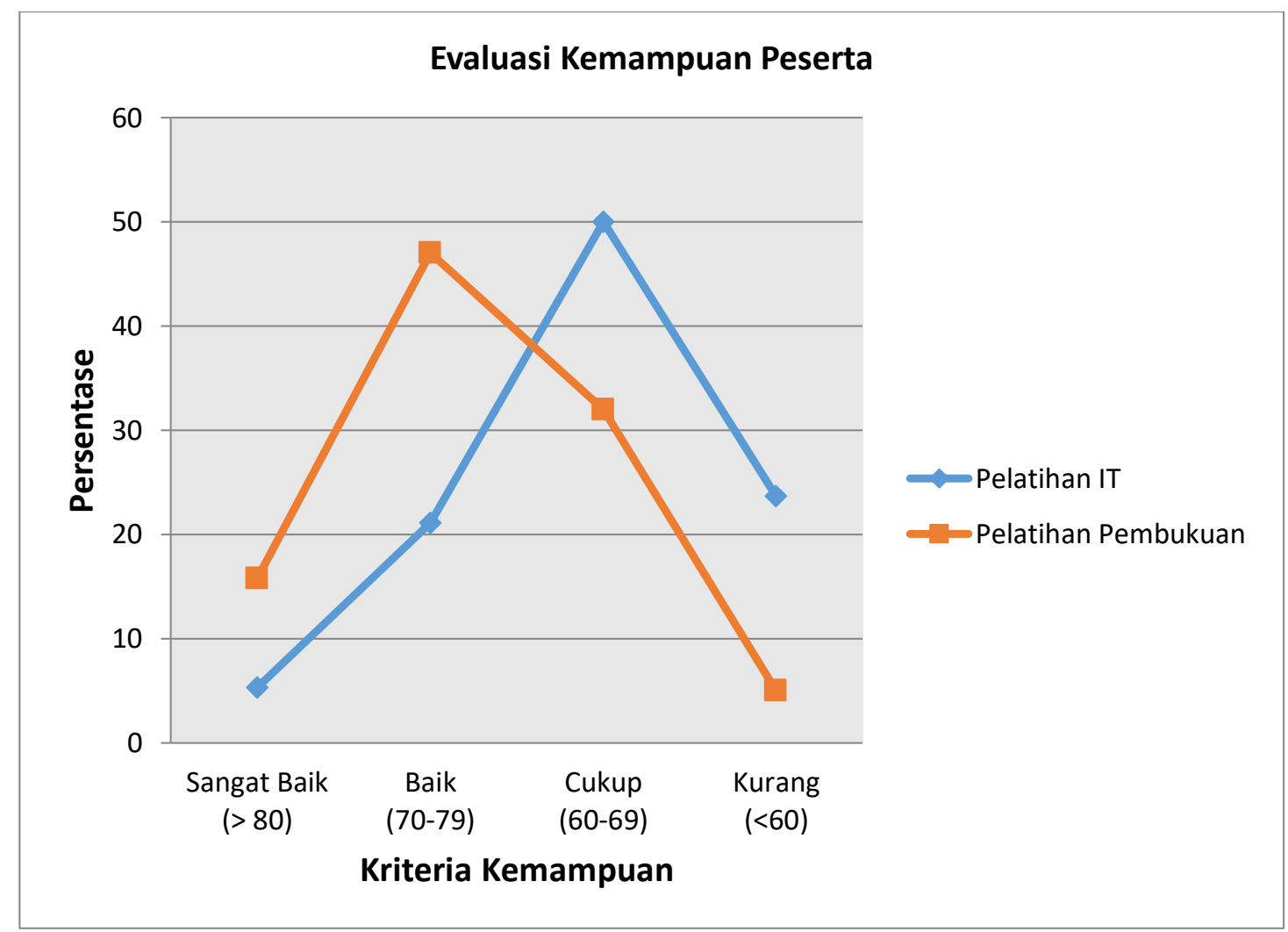

Gambar 6. Grafik Evaluasi Kemampuan Peserta

\section{3) Pembahasan Pasca Pemberian Bantuan Alat} Indikator keberhasilan kegiatan dapat dilihat ketika setelah selesai kegiatan dilakukan. Evaluasi dilakukan dengan pemantauan selama 1 bulan selesai kegiatan untuk melihat kelanjutan dari kegiatan ini dimana peserta kegiatan sudah memanfaatkan bantuan alat yang diperoleh dari pengabdi yang diberikan kepada masing-masing kelompok yaitu Oven Roti dengan 3 rak dan sealer sebagai alat pengemas Produk. Setelah diberikan alat tersebut tampak perubahan yang signifikan pada UMKM yang dibina tersebut. Pada saat belum dilaksanakan pembinaan UMKM Usaha Kuliner Roti yang biasanya hanya dapat memproduksi 10 $\mathrm{kg} /$ hari sejak diberikan bantuan dapat memproduksi 20 $\mathrm{kg} /$ hari, dengan harga yang masih sama yaitu seharga Rp. 1.000,-/ Buah. Pada saat sebelum dilakukan pembinaan produk tidak dibungkus dengan plastik secara perbuah akan tetapi diletakan dalam wadah plastik dengan isi sebanyak 50 Buah saat ini produk telah dilakukan pembungkusan dengan mengunakan sealer yang telah diberikan. Tingkat keberhasilan kegiatan dapat dilihat pada table dibawah ini.

Tabel 5. Indikator Perubahan Usaha

\begin{tabular}{|c|c|c|}
\hline Indikator & Awal & Akhir \\
\hline $\begin{array}{l}\text { - Dengan } \\
\text { diberikan } \\
\text { pelatihan } \\
\text { pemasaran } \\
\text { online (blog) }\end{array}$ & $\begin{array}{l}\text { - Pemasaran } \\
\text { hanya } \\
\text { disekitar } \\
\text { lingkungan }\end{array}$ & $\begin{array}{l}\text { - Pemasaran } \\
\text { sudah } \\
\text { menggunakan } \\
\text { blog dan sosial } \\
\text { media }\end{array}$ \\
\hline $\begin{array}{l}\text { - Dengan } \\
\text { diberikan } \\
\text { Oven }\end{array}$ & $\begin{array}{l}\text { - Produksi } \\
10 \text { kg/hari }\end{array}$ & $\begin{array}{ll}\text { - Produksi } & 20 \\
\text { kg/hari } & \end{array}$ \\
\hline $\begin{array}{l}\text { - Dengan } \\
\text { diberikan } \\
\text { sealer } \\
\text { kemasan }\end{array}$ & $\begin{array}{l}\text { - Tidak } \\
\text { dibungkus } \\
\text { dan kurang } \\
\text { hiegienis } \\
\end{array}$ & $\begin{array}{l}\text { - Sudah } \\
\text { dibungkus } \\
\text { dengan plastik }\end{array}$ \\
\hline
\end{tabular}




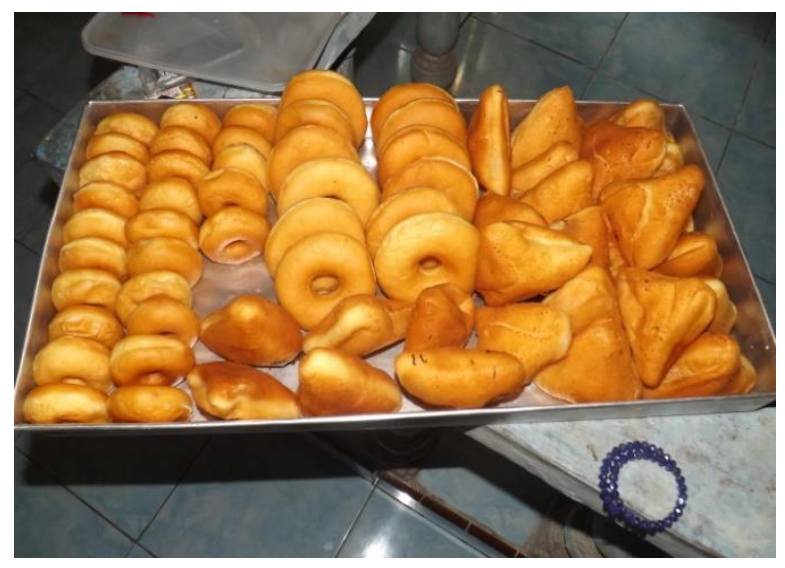

Gambar 7. Produk sebelum diberi sealer

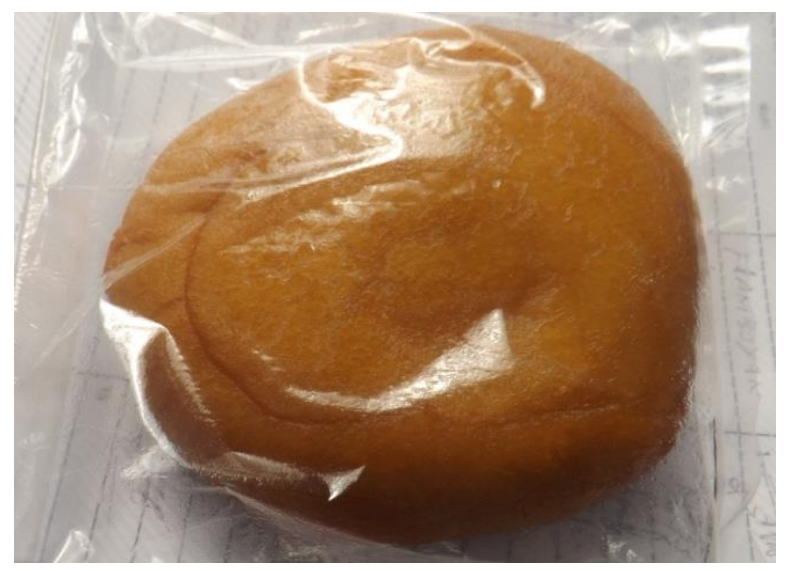

Gambar 8. Produk dengan sesudah diberi sealer

\section{KESIMPULAN}

Berdasarkan hasil kegiatan IbM Kelompok Usaha Rumah Tangga Kuliner Roti di Kabupaten Simalungun maka dapat disimpulkan sebagai berikut:

1) Peserta kegiatan telah memiliki pengetahuan dan Keterampilan tentang Pendampingan dan Penyuluhan Kuliner Roti ditinjau dari sisi Kesehatannya dengan konsentrasi materi Pemilihan Kandungan komposisi Bahan, Pengolahan Produk Sisa, kebersihan produk, kebersihan alat dengan nilai rata-rata 77,89 dengan kategori Baik

2) Kedua kelompok mitra telah mendapatkan bantuan oven

3) Kedua kelompok mitra telah mendapatkan sealer untuk mengemas produk kuliner roti

4) Kedua kelompok mitra dibantu untuk melakukan promosi dengan back drop di depan tempat usaha mitra sebagai mitra LPM Unimed

5) Walaupun untuk pemasaran Online kurang maksimal karena keterbatasan jaringan internet dan tidak tersedianya laptop pada mitra akan tetapi blog pemasaran kedua mitra telah mampu memasarkan produk dengan nama http://umkmanugrah.blogspot.co.id dan http://bahapaljaya.blogspot.co.id/.
Selain itu yang yang juga menjadi tugas pengabdi untuk tahun berikunya yang diinginkan oleh mitra antara lain:

1) Pengurusan label halal pada produk kuliner mitra

2) Pengurusan izin usaha

3) Izin produksi industri rumah tangga

4) Mesin pengadon roti dengan kapasitas $10-20 \mathrm{~kg}$

5) Desain kemasan setelah memiliki label halal dan P-IRT

6) Menggunakan website untuk pemasaran online dari Usaha kecil menengah kuliner roti tidak hanya Blog

\section{DAFTAR PUSTAKA}

Badan Koordinasi Keluarga Berencana Nasional, 2015, Pendataan Keluarga Tahun 2015, Badan Koordinasi Keluarga Berencana Nasional, Jakarta.

Irfandi Dan Taufik Hidayat, 2017, Pemanfaatan Serbuk Limbah Mebel dengan Metode Pengkomposan pada Media Tanam Jamur Tiram di Desa Mekar Sari Kecamatan Deli Tua, Prosiding Seminar Nasional Hasil Pengabdian Masyarakat 2017, Lembaga Pengabdian masyarakat, Universitas Negeri medan Halaman 69-76

Irfandi, 2015, Peningkatan Pendapatan Anggota Kelompok UPPKS Manalagi Kecamatan Bilah Hulu Labuhan Batu Dengan Menggunakan Oven Serbaguna, Jurnal Lembaga Pengabdian Kepada Masyarakat, volume 21 No. 80 tahun XXI Juni 2015, Unimed. Halaman 33-38

Irfandi,dkk 2015, Pemberdayaan UPPKS Bintang Kecamatan Batang Kuis Berbasis Teknologi Tepat Guna, Jurnal Lembaga Pengabdian Kepada Masyarakat, volume 21 No. 82 tahun XXI Desember 2015, Unimed. Halaman 53-59

Kementerian Keuangan Republik Indonesia. 2011. Potensi Perusahaan UKM untuk Go Public. Badan Pengawas Pasar Modal Dan Lembaga Keuangan, Depkeu RI. Jakarta

Tim Penyusun, 2013, Data Monografi Nagori Dolok Maraja, Nagori Dolok Maraja, Kabupaten Simalungun, Propinsi Sumatera Utara

Nasution H.A. Bustanul A.N Mukhammad S., 2001, Membangun Spirit Entrepreneur Muda Indonesia, Jakarta, Gramedia.

Santoso. 2009. Permasalahan Industri Kecil Rumah. http://ssantoso.blogspot.com. Diakses 3 Februari 2015.

Simanungkalit Y. 2015. Perkembangan Home Industri Makanan Ringan Di Nagori Perlananan Kecamatan Bandar Kabupaten Simalungun 1962-2011 Analisa Sejarah Perekonomian. http://digilib.unimed.ac.id. Diakses tanggal 10 Febuari 2015. 